\title{
High Temperatures Activate Local Viral Multiplication and Cell-to-Cell Movement of Melon necrotic spot virus but Restrict Expression of Systemic Symptoms
}

\author{
K. Kido, C. Tanaka, T. Mochizuki, K. Kubota, T. Ohki, J. Ohnishi, L. M. Knight, and S. Tsuda
}

First author: The Yokohamaueki Co. Ltd., Minami, Yokohama 232-8587, Japan; second author: Southern Prefectual Horticulture Institute, Chiba Prefecture Agriculture Research Center, Tateyama, Chiba 294-0014, Japan; third, fifth, sixth, seventh, and eighth authors: National Agricultural Research Center, Tsukuba, Ibaraki 305-8666, Japan; and fourth author: National Agricultural Research Center for Kyushu Okinawa Region, Koshi, Kumamoto, 861-1192, Japan.

Accepted for publication 24 August 2007.

\begin{abstract}
Kido, K., Tanaka, C., Mochizuki, T., Kubota, K., Ohki, T., Ohnishi, J., Knight, L. M., and Tsuda, S. 2008. High temperatures activate local viral multiplication and cell-to-cell movement of Melon necrotic spot virus but restrict expression of systemic symptoms. Phytopathology 98:181-186.

The infection of melon plants by Melon necrotic spot virus (MNSV) and the development of necrotic disease symptoms are a seasonal occurrence in Japan, which take place between winter and early summer, but not during mid-summer. In this paper we investigate the effect of three different temperatures $\left(15,20\right.$, and $\left.25^{\circ} \mathrm{C}\right)$ on the local and systemic expression of MNSV in melon plants. Previously, the incidence of plants expressing systemic symptoms caused by MNSV and other viruses was
\end{abstract}

ABSTRACT found to be greater at temperatures less than $20^{\circ} \mathrm{C}$. In this study, our temperature-shift experiments support previous studies that found the expression of systemic symptoms increases as temperature falls from 25 to $20^{\circ} \mathrm{C}$ and decreases as temperature rises from 20 to $25^{\circ} \mathrm{C}$. However, MNSV replication in melon cells and local viral movement within leaves following the inoculation of melon protoplasts or cotyledons were more frequent at $25^{\circ} \mathrm{C}$ than at 15 or $20^{\circ} \mathrm{C}$.

Additional keywords: global climate change, methyl bromide, Olpidium bornovanus, posttranscriptional gene silencing, soilborne disease, symptom development.
The melon Cucumis melo L. is widely grown in tropical and temperate zones worldwide, and is one of the most economically important vegetable crops in Japan. A popular cultivar is the 'Earl's Favorite', which was originally introduced to Japan from the United Kingdom in 1925. The four major types of Earl's Favorite are the smooth-skin melon, oriental picking melon, green-fresh netted melon, and red-fresh netted melon (31). The latter two types have outstanding taste and aroma therefore command a high market price.

Year-round Japanese melon production is made possible by three cultivation systems: winter forced cultivation from November to March, spring semi-forced cultivation from April to July, and autumn late-raising cultivation from August to December. However, melon plants suffer from a range of plant diseases, including necrotic spot disease, fusarium wilt, downy mildew, powdery mildew, and gummy stem blight. These diseases, combined with Melon necrotic spot virus (MNSV) infection, cause notable economic loss $(2,10,12,14,30,39)$. In infected melons, the field symptoms usually develop during the period between planting and harvest. Several types of systemic symptoms have been observed in true leaves at various plant growth stages (11, 14,18,39), including necrosis of the large mesophyll. Necrosis also occasionally appears on the stem and petioles. The most serious damage results from the development of airspaces within the fruit, which leads to the deterioration of taste. Once a melon field is contaminated with MNSV, it is difficult to harvest highquality fruit since the virus is easily transmitted through the field

Corresponding author: S. Tsuda; E-mail address: shinyat@ affrc.go.jp

doi:10.1094/PHYTO-98-2-0181

(c) 2008 The American Phytopathological Society by the soilborne obligatory fungus Olpidium bornovanus $(6,7$, $11,19,20)$.

MNSV is a spherical virus that is $30 \mathrm{~nm}$ in diameter. It is a member of the genus Carmovirus, which belongs to the family Tombusviridae. Since it was first discovered in 1960 in Japan (14), the disease caused by MNSV infection has been found in several melon producing areas of the world $(11,14,17,18)$ and, more recently, in the United States, Greece, Sweden, and Spain $(2,10,12,16,30)$. MNSV is transmitted by seed or the fungal vector, and infects melons, especially the Earl's Favorite cultivar (33). Soil fumigation by methyl bromide, which is used between cultivations, is the only chemical treatment that effectively prevents MNSV from spreading. However, the Montreal protocol forbids the use of this chemical in developed countries after 2005 for environmental reasons. Consequently, alternative strategies to control virus disease are required.

MNSV disease symptoms are frequently observed during winter to early summer and during cool summers with a long rainy season, such as that observed in Chiba Prefecture, Japan in June 2003. We suspect this is due to environmental conditions, such as temperature and photoperiod, influencing symptom development (11). In this report we show the cause of enhanced incidence of MNSV in melon plants at low temperature conditions.

\section{MATERIALS AND METHODS}

Viral inoculation and plant growth conditions. The following MNSV isolates were collected from infected melons from each of the corresponding production areas in Japan: MNSVChiba (accession no. AB250684) from the Chiba Prefecture, MNSV-Yamaguchi (accession no. AB250687) from the Yamaguchi Prefecture, and MNSV-Kouchi (accession no. AB250685) 
from the Kochi Prefecture. The following isolates from the Genebank of the National Institute of Agrobiological Sciences were also employed: MNSV-NH (17, accession no. AB044291), MNSV-NK (17, accession no. AB044292), and MNSV-S (14, accession no. D29663).

C. melo L. cv. Miyabi-syunjyuukei (Yokohamaueki Co. Ltd., Yokohama, Japan), which lacks the nsv resistance gene and is susceptible to MNSV, was used as the assay plant. Melon seeds were sown in pots at $30^{\circ} \mathrm{C}$ under 16 -h light $(30,000$ lux $) / 8$-h dark conditions with metal halide lamps. After germination, the seedlings were kept at $22.5^{\circ} \mathrm{C}$. A set of cotyledons on 7-day-old seedlings was mechanically inoculated with the sap of MNSVinfected melon leaves and an abrasive dust, Carborundum. The roots of 14-day-old seedlings were inoculated with each MNSV isolate to model viral soil transmission. Soil was washed from the roots with flowing water. The roots were then mechanically inoculated with the sap of MNSV-infected leaves and Carborundum dust. After inoculation, the seedlings were sequentially transplanted into new pots with fresh sterile soil.

Four growth conditions with varying temperature categories for melon plants were established: category 1 , which were maintained at $20^{\circ} \mathrm{C}$ for 28 days postinoculation (dpi); category 2 were maintained at $20^{\circ} \mathrm{C}$ for $14 \mathrm{dpi}$, then moved to $25^{\circ} \mathrm{C}$ for another 14 days; category 3 were maintained at $25^{\circ} \mathrm{C}$ for $14 \mathrm{dpi}$, then moved to $20^{\circ} \mathrm{C}$ for another 14 days; category 4 were kept at $25^{\circ} \mathrm{C}$ constantly for 28 dpi. Each category contained 16 melon plants that had been inoculated.

MNSV melon protoplast inoculation and northern blot analysis. The coat of each melon seed was removed, sterilized in $70 \%$ ethanol and $0.5 \%$ sodium hypochlorite, and sown on germination medium (Murashige and Skoog solution, 3\% sucrose, $0.05 \% \mathrm{MES}$, and $1 \%$ agarose [pH 5.7]) in a plastic container. The seeds were grown at $27^{\circ} \mathrm{C}$ under a $16-\mathrm{h} / 8$-h light/dark regime for 5 days. The cotyledons were cut into $1 \times 1 \mathrm{~mm}$ pieces and incubated for $3 \mathrm{~h}$ in an enzyme solution (1\% Cellulase Onozuka RS, 0.01\% Pectolyase Y23, 0.4 M mannitol, and 0.1 M glycine). The crude protoplast suspension was filtered through a nylon mesh and washed three times with $0.4 \mathrm{M}$ of mannitol ( $\mathrm{pH} 5.8$ ), followed by $3 \mathrm{~min}$ centrifugation at $300 \times \mathrm{g}$. The band containing protoplasts was isolated and resuspended in an MES-mannitol solution (5 mM MES, $70 \mathrm{mM} \mathrm{KCl}$, and 0.3 M mannitol, pH 5.8). Protoplasts $\left(5.0 \times 10^{5}\right.$ cells $)$ were inoculated with RNA in a polyethylene glycol solution (MES-mannitol containing $40 \%$ polyethylene glycol, 6,000), which was synthesized on ice for $30 \mathrm{~min}$ in vitro transcription from the plasmid pTMNW1 containing fulllength MNSV-Chiba cDNA driven by a T7 RNA promoter (20). After inoculation, protoplasts were washed three times with a protoplast culture medium (Murashige and Skoog solution, $0.0001 \%$ thiamine- $\mathrm{HCl}, 0.01 \%$ myo-inositol, $0.00002 \%$ 2,4-D, and $1 \%$ sucrose, $\mathrm{pH} 5.8$ ) followed by centrifugation at $300 \times \mathrm{g}$ for $5 \mathrm{~min}$. Inoculated protoplasts were resuspended in protoplast culture medium and maintained in the dark at $15^{\circ} \mathrm{C}, 20^{\circ} \mathrm{C}$, and $25^{\circ} \mathrm{C}$ prior to total RNA extraction using the TRIzol LS reagent (Invitrogen, Carlsbad, CA) according to the manufacturer's instructions.

The accumulation of viral genomic and subgenomic RNA was analyzed by northern blot analysis. Following denaturation with glyoxal, total RNA was separated by electrophoresis on a $1 \%$ agarose gel, transferred to a Hybond-N membrane (GE Healthcare Bio-sciences, Piscataway, NJ), and fixed by ultraviolet crosslinking and baking at $80^{\circ} \mathrm{C}$. The membrane was then stained with $0.02 \%$ methylene blue solution for imaging with an enhanced chemiluminescence (ECL) direct acid labeling and detection system (GE Healthcare Bio-sciences). A riboprobe against the MNSV-Chiba coat protein gene, which is able to simultaneously detect MNSV genomic and two subgenomic RNAs, was enzymatically produced in vitro from the cDNA clone plasmid, pMNCP1, which was cloned into pCR-Blunt II-TOPO (Invitro- gen). The riboprobe was labeled with horseradish peroxidase and hybridized according to the manufacturer's instructions, then the chemiluminescence and methylene blue dye were quantified with the VersaDoc 5000 (Bio-Rad Laboratories Inc., Hercules, CA). To compare viral RNA replication at the different temperatures, the band intensities were quantified by a digital imaging analyzer and Quantity One software (Bio-Rad Laboratories Inc.) and normalized with $28 \mathrm{~S}$ ribosomal RNA (rRNA). The relative value of accumulated genomic RNA was calculated after the background, a corresponding area of mock inoculated tissue, was subtracted.

Detection of MNSV cell-to-cell movement by tissue blotting. Cotyledons from plants inoculated at 2, 3, and 4 dpi had a single layer of the abaxial epidermis removed using a razor blade (10 leaves at each time point), were sandwiched between two pieces of filter paper, and vacuum dried overnight at room temperature to transfer sap onto the filter paper. Immunological detection of MNSV was performed according to previously described methods (32). The filter paper was washed briefly with $2 \%$ Triton X-100 to remove plant pigments, then blocked with $3 \%$ skim milk in phosphate-buffered saline containing 0.05\% Tween 20 (PBST). The filter paper was then treated with an anti-MNSV antibody (Japan Plant Protection Association, Tokyo, Japan) diluted at 1:2,000 in PBST-3\% skim milk for $1 \mathrm{~h}$ at $37^{\circ} \mathrm{C}$. This was followed by treatment with alkaline phosphatase-conjugated antirabbit immunoglobulin $\mathrm{G}$ ( $\mathrm{IgG}$ ) antibody (MP Biomedicals, Inc, Aurora, $\mathrm{OH}$ ) in PBST-3\% skim milk for $1 \mathrm{~h}$ at room temperature. After washing with PBST, the filter paper was stained with chromagenic color substrates 5-bromo-4-chloro-3-indolylphosphate toluidinium (BCIP)/nitroblue tetrazolium (NBT) (Purple Liquid Substrate System, Sigma-Aldrich Corp., St. Louis, MO).

To identify viral infection areas, images of the tissue blot were scanned and digitized using the graphic analysis program Image $\mathbf{J}$ software (National Institutes of Health, Bethesda, MD) (1). To account for differential leaf expansion at each temperature, the actual area considered positive for MNSV reaction was calculated as a proportion of the whole leaf, and found statistically significant by the Tukey-Kramer honestly significantly different (HSD) test.

\section{RESULTS}

Effect of temperature difference on MNSV disease incidence on melon plants. We observed systemic symptoms of MNSV in melon plants maintained at 15,20 , and $25^{\circ} \mathrm{C}$, to confirm that lower temperatures increased incidence of MNSV on plants as previously reported by Mallor et al. (16). Systemic symptoms is defined here as the appearance of numerous tiny necrotic spots on the young upper true leaves postinoculation onto cotyledons (Fig. 1A). At $7 \mathrm{dpi}$, no plants maintained at $15^{\circ} \mathrm{C}$ had developed systemic symptoms, however, at 20 and $25^{\circ} \mathrm{C}$ less than $20 \%$ and $10 \%$ of plants displayed systemic symptoms, respectively (Fig. 1B). At $14 \mathrm{dpi}$, the incidence of disease in plants maintained at 15 and $20^{\circ} \mathrm{C}$ had increased to approximately $30 \%$ and as much as $50 \%$, respectively, but at $25^{\circ} \mathrm{C}$ remained at $10 \%$. At $21 \mathrm{dpi}$, disease incidence at 15 and $20^{\circ} \mathrm{C}$ was $90 \%$ and $80 \%$, respectively, but at $25^{\circ} \mathrm{C}$ less than $20 \%$ of plants has developed symptoms. In most cases plants maintained at $25^{\circ} \mathrm{C}$ for $21 \mathrm{dpi}$ showed almost no systemic symptoms on the upper true leaves, despite severe necrosis on the inoculated cotyledons.

To confirm that this phenomenon was true for all MNSV isolates, a comparative test was performed on MNSV-Chiba, MNSV-S, MNSV-Yamaguchi, MNSV-Kouchi, MNSV-NK, and MNSV-NH. All of the MNSV strains developed enhanced systemic symptoms at lower temperatures (data not shown). Of these, the MNSV-Chiba, MNSV-NH, and MNSV-Yamaguchi isolates showed a higher incidence of systemic symptoms at all temperatures. These results indicate that MNSV systemic infection and the appearance of necrosis is enhanced by the lower 
temperatures within the melon growth temperature range, confirming work of Mallor et al. (16).

Effect of temperature shift on disease incidence. To analyze the relationship between the developmental stage and effect of low temperatures on the expression of systemic symptoms, we performed a temperature-shift experiment using 16 melon plants in each category, in which MNSV was mechanically inoculated into the roots of melon seedlings as a model of viral soil transmission. As Figure 2 shows, maintaining plants at a fixed temperature of $20^{\circ} \mathrm{C}$ (category 1), disease incidence was measured at $100 \%$, however, when maintained at $25^{\circ} \mathrm{C}$ for 28 days (category 4 ), disease incidence was only at $12.5 \%$. Shifting the temperature from 20 to $25^{\circ} \mathrm{C}$ (category 2) after 14 days, lowered the disease incidence to approximately $31.3 \%$. However, by moving plants maintained at $25^{\circ} \mathrm{C}$ for 14 days to $20^{\circ} \mathrm{C}$ for 14 days (category 3 ), the disease incidence increased to $68.8 \%$. These results demonstrate that it is more crucial to decreased MNSV incidence to maintain a high temperature during the second 14 days, just after transplantation into fields.

MNSV replication in melon protoplasts. To determine the effect of temperature on MNSV replication at the single-cell level, we compared the accumulation of MNSV RNA in melon protoplasts incubated at three different temperatures: 15,20 , and $25^{\circ} \mathrm{C}$. Total RNAs extracted from protoplasts at 12, 24, 36, and $48 \mathrm{~h}$ postinoculation (hpi) were analyzed by northern blotting. Three major bands were observed: a $4.3 \mathrm{~kb}$ band representing MNSV genomic RNA, and 1.9 and $1.6 \mathrm{~kb}$ bands representing subgenomic RNAs (Fig. 3A, upper panel).

The accumulation of genomic RNA in protoplasts grown at $25^{\circ} \mathrm{C}$ reached saturation by $24 \mathrm{hpi}$, which was rapid compared with the other temperatures, and then gradually decreased after that time. The accumulation of RNA at $20^{\circ} \mathrm{C}$ reached a plateau at 36 hpi. Although RNA levels slowly increased but did not reach saturation during the experimental period at $15^{\circ} \mathrm{C}, 28 \mathrm{~S}$ rRNA normalization showed genomic RNA accumulation in protoplasts at all temperatures continued to increase even at 48 hpi (Fig. 3B). MNSV RNA levels at $25^{\circ} \mathrm{C}$ were higher than both 15 and $20^{\circ} \mathrm{C}$ for all time points. By contrast, RNA accumulation at $15^{\circ} \mathrm{C}$ remained low in concentration. These results indicate that MNSV accumulates in protoplasts to a higher level when maintained at temperatures over $20^{\circ} \mathrm{C}$, and particularly when maintained at $25^{\circ} \mathrm{C}$, than at $15^{\circ} \mathrm{C}$. Methylene blue staining for $28 \mathrm{~S}$ rRNA (Fig. $3 \mathrm{~A}$, lower panel) and the microscopic observation of protoplasts (data not shown) revealed that cell numbers started to decrease after $36 \mathrm{hpi}$ at all temperatures, whereas cell numbers of protoplasts with mock inoculation remained constant (data not shown).
Rate of cell-to-cell movement from necrotic lesions on inoculated leaves. MNSV necrotic lesions spread from the infected cell through cell-to-cell movement on inoculated cotyledons. The effect of temperature on the rate of necrotic lesion formation and cell-to-cell movement of MSNV was assessed by visual inspection and tissue-blot analysis of inoculated cotyledons at 15,20 , and $25^{\circ} \mathrm{C}$ every day for 9 dpi (Fig. $4 \mathrm{~A}$ ). At $25^{\circ} \mathrm{C}$, necrotic spots were first observed at 2 to $3 \mathrm{dpi}$, and had quickly expanded by $6 \mathrm{dpi}$. At $20^{\circ} \mathrm{C}$, necrotic spots were first observed at 5 to $7 \mathrm{dpi}$. At $15^{\circ} \mathrm{C}$, chlorotic spots were first observed at 7 to 9 dpi and later developed into necrotic spots. Tissue-blot analyses were carried out on inoculated cotyledons to confirm that observed expansion of necrotic lesions was due to cell-to-cell movement and not leaf expansion (Fig. 4B). At 2 and 3 dpi, no significant difference in the proportion of necrotic lesion area to

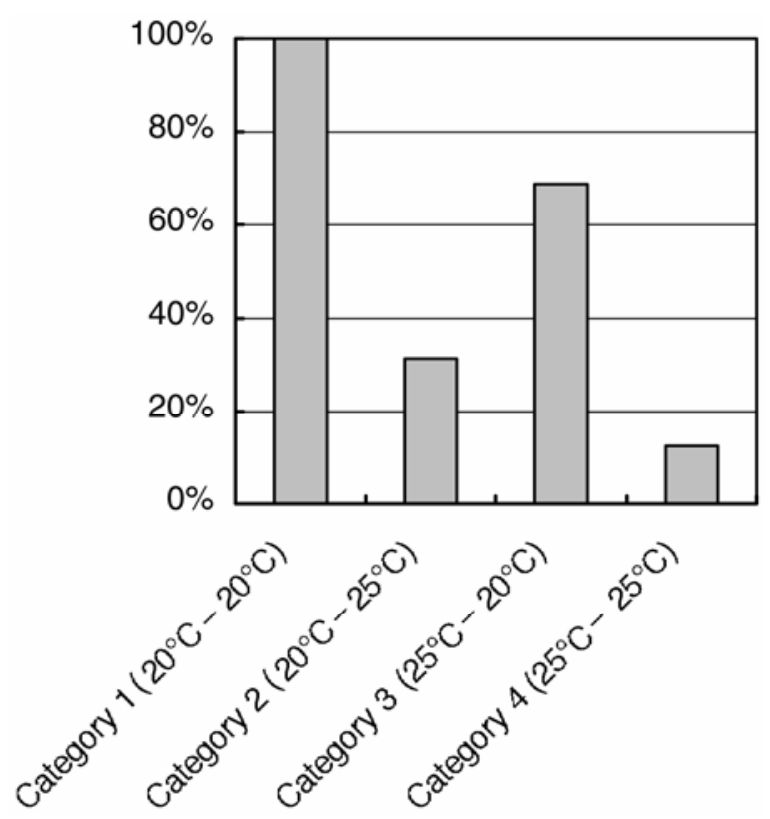

Fig. 2. Effects of temperature shift on systemic symptom expression in Melon necrotic spot virus (MNSV)-inoculated melon plants. The roots of 16 melon seedlings at the second-leaf stage were inoculated with MNSV-Chiba according to four temperature regimes: continuous growth at $20^{\circ} \mathrm{C}$ for 28 days (category 1 ); $20^{\circ} \mathrm{C}$ for 14 days then $25^{\circ} \mathrm{C}$ for 14 days (category 2 ); $25^{\circ} \mathrm{C}$ for 14 days then $20^{\circ} \mathrm{C}$ for 14 days (category 3 ); and continuous growth at $25^{\circ} \mathrm{C}$ for 28 days (category 4 ).
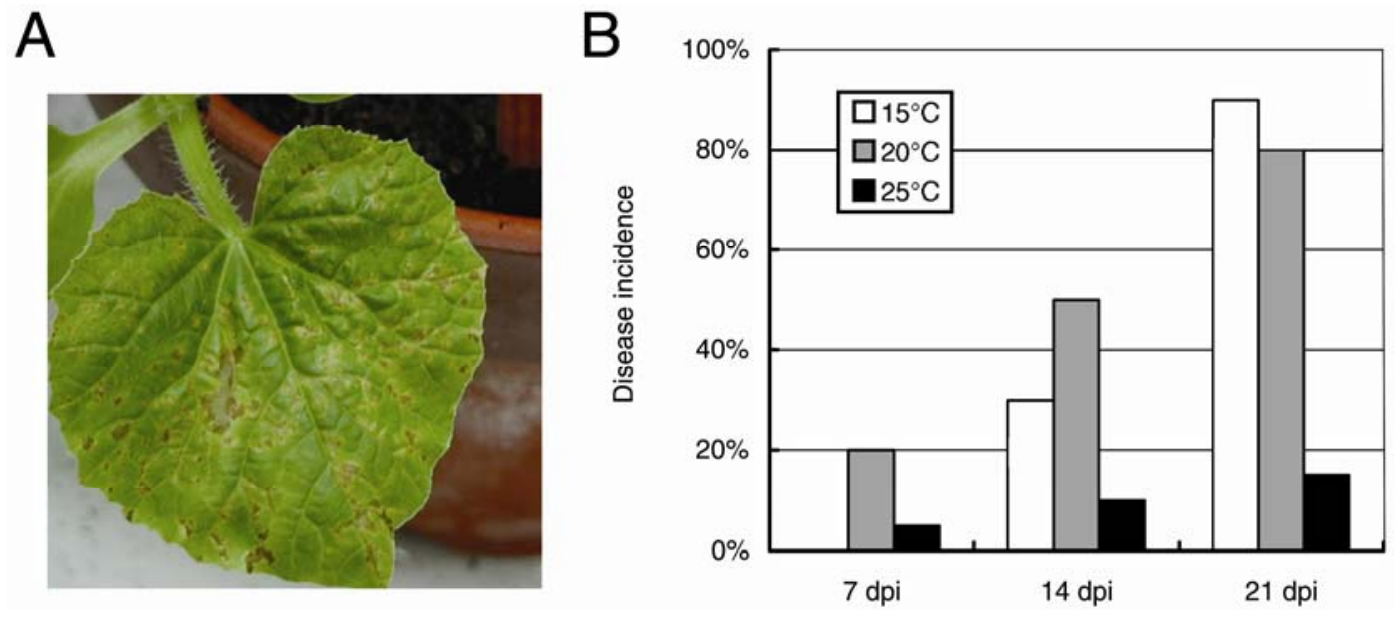

Fig. 1. Systemic symptom expression of Melon necrotic spot virus (MNSV)-inoculated melon plants at the seedling stage grown at three different temperatures. A, Systemic necrotic symptoms caused by MNSV-Chiba on a true leaf of a melon. B, Incidence of melon plants expressing systemic symptoms at three different temperatures $(n=40)$. 
background leaf expansion at any temperature was found. At $4 \mathrm{dpi}$, the MNSV-infected area was much larger at $25^{\circ} \mathrm{C}$ than at any other temperature (Fig. 4C). These results confirm that the rate of MNSV-induced necrotic lesion formation and cell-to-cell expansion increases as the temperature increases.

\section{DISCUSSION}

The present study confirms earlier findings that the incidence of MNSV disease is affected by plant growth temperature $(11,16)$. We also found that temperatures below $20^{\circ} \mathrm{C}$ enhanced the systemic symptom development of MNSV; the degree of damage decreased gradually as the temperature increased; and viral replication and spread increased above $25^{\circ} \mathrm{C}$.

Past experiments on viral replication of plant RNA viruses support our conclusion that necrotic symptoms at low temperature are due to viral systemic movement rather than the activities of local replication. There are several possibilities to explain the difference in MNSV symptoms at 20 and $25^{\circ} \mathrm{C}$. Other possibilities may be related to the mechanism of virus spread through plant tissues, interaction with different plant membranes, host defense and posttranscriptional gene silencing (PTGS), stability of RNA-dependent RNA polymerase (RdRp), and host metabolism. Here we discuss the four topics that could affect the enhancement of MNSV disease at low temperatures: (i) stem-loop enhancer disruption, (ii) RdRp conformation, (iii) cell-to-cell movement, and (iv) RNA silencing-mediated plant defense inhibition.

It has been found that low temperatures exacerbate symptoms and increase virus content for many viral diseases, whereas symptoms are often attenuated at high temperatures, a phenomenon also termed as 'heat masking' (34). Some of these plant viruses include Mirafiori lettuce big-vein virus (MLBVV), Wheat yellow mosaic virus (WYMV), and Banana streak virus (BSV) in plantains and bananas $(9,15,25)$. It was shown by Szittya et al. (34) that low temperatures inhibited virus triggered PTGS, however siRNAs were abundant at higher temperatures $\left(27^{\circ} \mathrm{C}\right)$. They showed that systemic infection of Cymbidium ringspot virus (CymRSV)-infected Nicotiana benthamiana was prevented due to PTGS at $27^{\circ} \mathrm{C}$; however from 15 to $24^{\circ} \mathrm{C}$, PTGS activity was inhibited and CymRSV was able to systemically infect $N$. benthamiana (34). Furthermore, it is speculated that PTGS suppresses viral systemic infection at several stages.

Some plant virus genomes encode PTGS suppressor proteins that enable limited viral movement, such as phloem-to-mesophyll and external-to-internal phloem. This suggests the existence of tissue-specific PTGS that prevents viral systemic infection $(3,28$, 29,36,37). Szittya et al. (34) propose that DICER activity might be compromised at lower temperatures. This demonstration that RNA silencing-mediated plant defense is temperature sensitive can adequately explain the systemic movement of MNSV in melons at high temperatures, whereas plants grown at low temperatures can be affected by systemic infection we observed.

Research on tombusvirus and carmovirus RNA replication has elucidated much information concerning the stability of RdRp and promoter region $(21,22,26,27)$. Panavas et al. (26) found that two hairpin structures and the single stranded region that separates them are important for positive strand synthesis. They believe that the hairpin secondary structures and replication enhancer promoter sequence may be involved in binding to the tombusvirus RdRp (26). Bozza et al. (5) found the secondary structure of the RNA oligonucleotide is a stable hairpin at $25^{\circ} \mathrm{C}$ and that hairpin stability single strand transition decreases from 30 to $45^{\circ} \mathrm{C}$, but remains highly reversible in that range. This is contradictory to findings with the animal virus, Dengue virus, in which virus titer was found to decrease with increasing temperature when viral replication was assessed at 35 to $39^{\circ} \mathrm{C}$ (4).

Previous studies have shown that for dengue virus, replication occurs between 15 to $40^{\circ} \mathrm{C}$ (maximum dsRNA produced at $30^{\circ} \mathrm{C}$ ) and is inhibited over $50^{\circ} \mathrm{C}$; and initiation by the $\mathrm{RdRp}$ is the temperature-limiting step (38). Although Yang et al. (38) admit that more research must be done to show whether the temperature sensitivity of RdRP applies to other RNA viruses, they demonstrate that de novo initiation by $\mathrm{RdRp}$ is inhibited at elevated temperatures above $50^{\circ} \mathrm{C}$, whereas elongation is thermostable in dengue virus from (38). Although results from animal viruses are important to note, the results may not apply to plant viruses as the temperature range of animal virus replication is confined to mammalian body temperatures. Therefore, as Yang noted, it is important to first confirm that their results apply to RNA viruses before making claims.

Another possibility is that cell-to-cell movement is affected by temperature. The movement proteins of MNSV fall into the double gene block system of movement of carmo-like viruses and some geminiviruses, in which the movement protein binds preferentially to single-stranded RNA in a non-sequence-specific manner which facilitates nonvirion, cell-to-cell movement. Navarro et al. (23) published results which showed that the movement proteins of MNSV double block movement proteins, p7A and p7B, have RNA-binding properties and membrane insertion sequences, respectively. Interestingly, they found that the biological function of the movement protein depends on physical and chemical properties of residues of secondary structure rather than primary structure. They also found that the second movement protein of MNSV p7B inserts in vitro into the endoplasmic reticulum (ER)
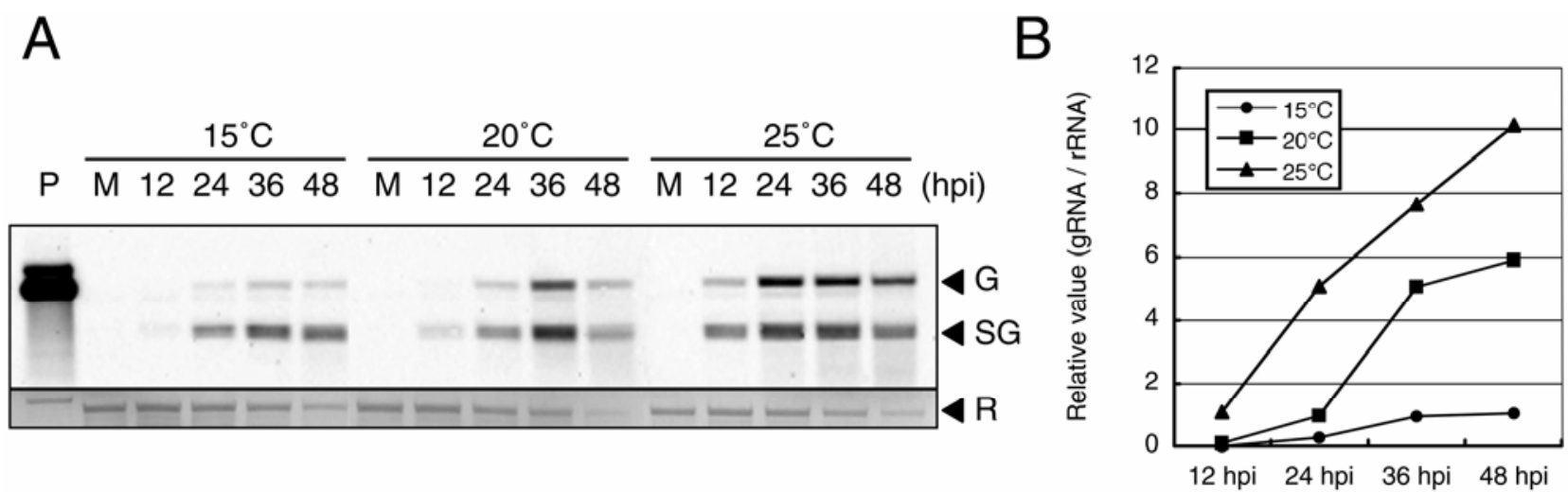

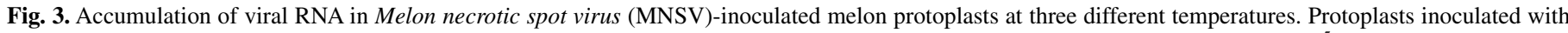

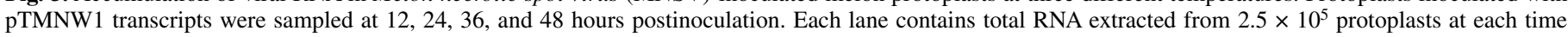

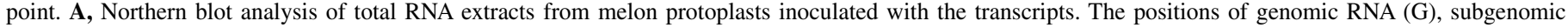

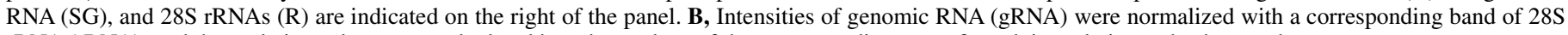
rRNA (rRNA), and then relative values were calculated based on values of the corresponding area of mock inoculation as background. 
lipid bilayer as an integral protein, assembly related to plasmodesmata gating. This may be facilitated by increased temperatures making cell-to-cell movement more likely at temperatures that make ER membranes more fluid, which is consistent with our observed increase in spread of virus at $25^{\circ} \mathrm{C}$. Alternatively, the stability of the MNSV nucleoprotein complex required for systemic movement might be affected by changes to the plant physiology that occur under low temperatures, suppressing MNSV systemic spreading in a plant.

Of all the possible explanations for our observed results of increased spread of virus particles, number of necrotic spots and decreased incidence of MNSV disease at higher temperature, the strongest support is from work showing that the plant defense mechanism of RNA silencing is temperature sensitive, and is inactivated at low temperatures (34).

Lastly, a novel suggestion for the temperature dependency comes from disease resistance genes at the nsv locus, which confers resistance to MNSV in melon, in melon cultivars with the resistance gene $(8,12,24)$. Although no support for this theory is available in MNSV research because melon plants used in this study have no resistant gene, studies with Tobacco mosaic virus (TMV) in tobacco have shown that plant resistance genes to viruses can be temperature sensitive. The $N$ gene-mediated hypersensitive response (HR) which confers resistance to TMV in tobacco is reversibly inactivated at elevated temperatures (37). At temperatures of $32^{\circ} \mathrm{C}$ and above, the $N$-mediated $\mathrm{HR}$ is suppressed and TMV moves systemically. However, if the plant is returned to $28^{\circ} \mathrm{C}$, HR is restored and necrosis occurs throughout the plant, followed by massive cell death mediated by the $N$ gene throughout all cells to which the virus has spread. Like the case of the $N$ gene, programmed cell death is inactivated at higher temperatures, our results show higher temperatures allow viral multiplication and cell-to-cell movement of MNSV, and local lesions are restricted. Although this work was performed with melon cultivars without the resistance gene, the temperature sensitivity of the $n s v$ resistance gene in melon will be tested in our future experiments. With all disease resistance genes we caution that the temperature sensitivity of transgenic cultivars be carefully tested before widespread integration into agricultural use, to prevent catastrophic failures due to temperature induced gene inactivation.

Depending on the mechanisms of transmission, interaction between vector and host, and effect of temperature on viral infection cycle, there can be a wide range of causes for each observed change on virus pathology. In this paper we show that MNSV symptoms are temperature sensitive and show remarkably increasingly destructive symptoms for melon crops at temperatures below $20^{\circ} \mathrm{C}$. This information may prove useful for melon growers in areas where the local climate drops during growing season. We recommend maintaining temperatures of over $20^{\circ} \mathrm{C}$ in greenhouses to greatly reduce the damage caused by MNSV, particularly during the cultivation period from winter to early summer. Furuki suggested that the high temperature and the long photoperiod of the summer season induce reduction of MNSV disease due to environmental conditions unfavorable for the $O$. bornovanus fungal vector (11). However, in contrast, it has also been shown that $O$. bornovanus multiplies more rapidly at temperatures from 28 to $30^{\circ} \mathrm{C}(6,19,35)$. Cultural practices aimed at fungal vector control, such as irrigation water heated to $70^{\circ} \mathrm{C}$, can be used to decrease the occurrence of viral infection transmitted underground by $O$. bornovanus. Recently, Japanese farmers have been successfully using heated irrigation water to control Olpidium, however, these results have not yet been published. This nonchemical control method is an environmentally friendly alternative to methyl bromide and we expect it will gain in popularity in the near future.

Our results also have important ecological implications. If the average temperature on the Earth rises as is predicted, 1.5 to $4.5^{\circ} \mathrm{C}$ degrees by the year 2050 , the climate will be in an unpredictable flux (13). Due to the unpredictable nature of major weather forming factors, such as ocean currents, evaporation, cloud cover, and changing precipitation, the predictability of local weather is expected to decrease (13). In order to understand possible changes in disease epidemiology in a changing climate, data demonstrating the affect of varying temperatures on virus replication, movement, and symptoms are needed. In the upcom-

A

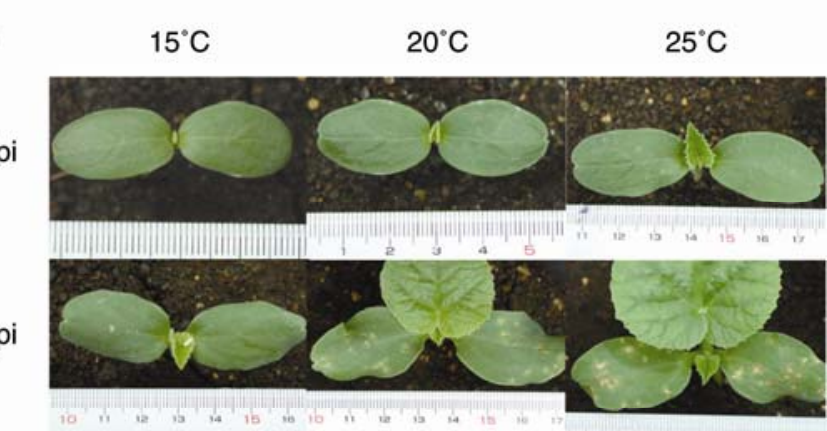

9 dpi

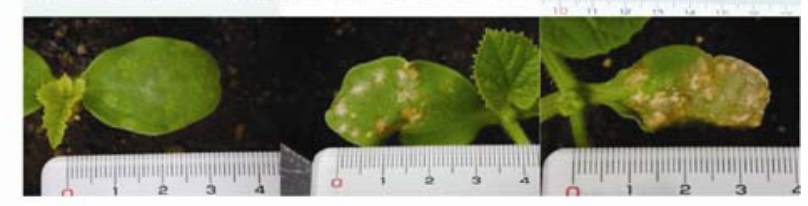

B

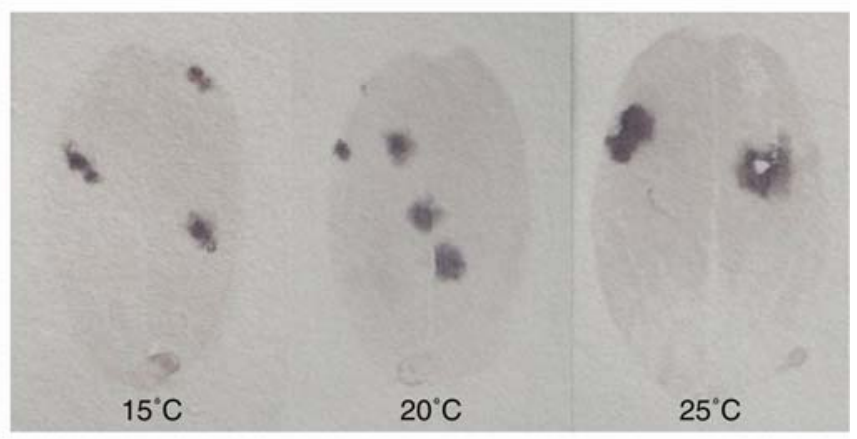

C

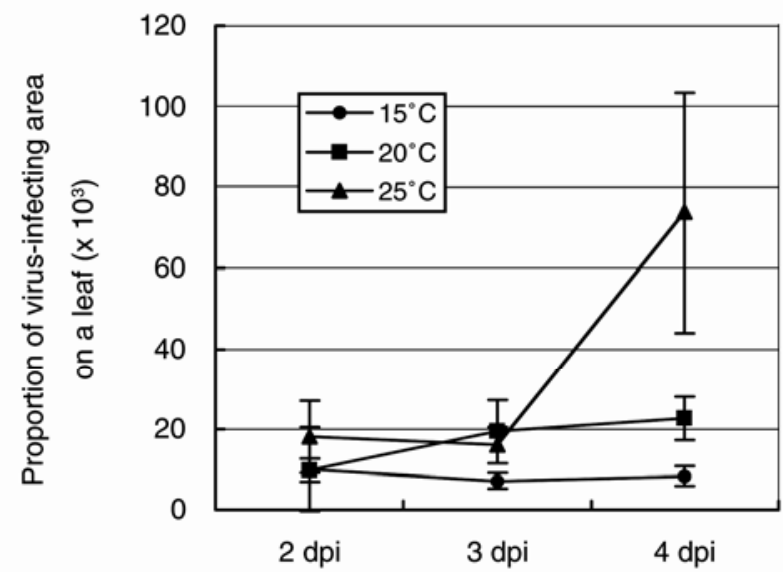

Fig. 4. Formation of local lesions on Melon necrotic spot virus (MNSV)inoculated melon cotyledons at three different temperatures. A, Cotyledons were inoculated with MNSV-Chiba then grown at 15,20 , or $25^{\circ} \mathrm{C}$. The ruler shows minimum divisions of $1 \mathrm{~mm}$. B, Tissue blotting of MNSV at 4 days postinoculation (dpi) in inoculated cotyledons at three different temperatures. $\mathbf{C}$, Spreading of MNSV in inoculated cotyledons was analyzed by tissue-blot analysis of leaves collected at 2, 3, and 4 dpi. 
ing decades of unpredictable changes in weather patterns expected due to global climate change, experiments on temperature affects on crop production will help growers across the globe to be better prepared for whatever those changes may be.

\section{ACKNOWLEDGMENTS}

We thank T. Meshi, and the National Institute of Agrobiological Sciences, Japan, for helpful comments and discussion. This study was supported, in part, by a Grant-in-Aid as part of The Research Project for Utilizing Advanced Technologies in Agriculture, Forestry and Fisheries administered by the Ministry of Agriculture, Forestry and Fisheries in Japan.

\section{LITERATURE CITED}

1. Abramoff, M. D., Magelhaes, P. J., and Ram, S. J. 2004. Image processing with image. J. Biophotonics Int. 11:36-42.

2. Avegelis, A. 1985. Occurrence of Melon necrotic spot virus in Crete (Greece). Phytopathol. Zeits. 114:365-372.

3. Barker, H., McGeachy, K. D., Ryabov, E. V., Commandeur, U., Mayo, M. A., and Taliansky, M. 2001. Evidence for RNA-mediated defense effects on the accumulation of Potato leafroll virus. J. Gen. Virol. 82:3099-3106.

4. Blaney, J. E., Jr., Johnson, D. H., Firestone, C.-Y., Hanson, C. T., Murphy, B. R., and Whitehead, S. S. 2001. Chemical mutagenesis of dengue virus type 4 yields mutant viruses which are temperature sensitive in vero cells or human liver cells and attenuated in mice. J. Virol. 75:9731-9740.

5. Bozza, M., Sheardy, R. D., Dilone, E., Scypinski, S., and Galazka, M. 2006. Characterization of the secondary structure and stability of an RNA aptamer that binds vascular endothelial growth factor. Biochemistry 45:7639-7643.

6. Campbell, R. N., and Sim, S. T. 1994. Host specificity and nomenclature of Olpidium bornovanus (=Olpidium radicale) and comparisons to Olpidium brassicae. Can. J. Bot. 72:1136-1143.

7. Campbell, R. N., Wipf-Scheibel, C., and Lecoq, H. 1996. Vector-assisted seed transmission of Melon necrotic spot virus in melon. Phytopathology 86:1294-1298.

8. Coudriet, D. L., Kishaba, A. N., and Bohn, G. W. 1981. Inheritance of resistance to Muskmelon necrotic spot virus in a melon aphid-resistance breeding line of muskmelon. J. Am. Soc. Hortic. Sci. 106:789-791.

9. Dahal, G., Hughes, J. d'A., Thottappilly, G., and Lockhart, B. E. L. 1998. Effect of temperature on symptom expression and reliability of Banana streak badnavirus detection in naturally infected plantain and banana (Musa spp.). Plant Dis. 82:16-21.

10. Diaz, J. A., Nieto, C., Moriones, E., and Aranda, M. A. 2002. Spanish Melon necrotic spot virus isolate overcomes the resistance conferred by the recessive $n s v$ gene of melon. Plant Dis. 86:694.

11. Furuki, I. 1981. Epidemiological studies on Melon necrotic spot. Shizuoka (Japan) Agric., Exp. Stn. Tech. Bull. No. 14.

12. Gonzalez-Garza, R., Gumpf, D. J., Kishaba, A. N., and Bohn, G. W. 1979. Identification, seed transmission, and host range pathogenicity of a California isolate of Melon necrotic spot virus. Phytopathology 69:340345.

13. Henson, R. 2006. The Rough Guide to Climate Change. Rough Guides, London,

14. Kishi, K. 1966. Necrotic spot of melon, a new virus disease. Ann. Phytopathol. Soc. Jpn. 32:138-144.

15. Maekawa, K., Sasaya, T., Fujii, H., Ishikawa, K., Kanto, T., and Aino, M. 2004. The effect of growth temperature on big-vein symptom and serological detection of Mirafiori lettuce virus and Lettuce big-vein virus in lettuce. Jpn. J. Phytopathol. 70:320-322.

16. Mallor, C., Alvarz, M., and Luis-Arteaga, M. 2003. A resistance to systemic symptom expression of Melon necrotic spot virus in melon. J. Am. Soc. Hortic. Sci. 128:541-547.

17. Matsuo, K., Kameya-Iwaki, M., and Ota, T. 1991. Two new strains of Melon necrotic spot virus. Ann. Phytopathol. Soc. Jpn. 57:558-567.

18. Matsuo, K. 2002. Study on the ecology of necrotic spot disease of melon in greenhouse. Nagasaki (Japan). Agric. Exp. Stn. Tech. Bul1. No. 3.
19. Matsuo, K., and Uchikawa, K. 2003. A method for detection of Melon necrotic spot virus and its vector in infected soil using young melon seedlings. Kyushu Plant Prot. Res. 49:29-32.

20. Mochizuki, T., Ohnisi, J., Ohki, T., Kanda, A., and Tsuda, S. Amino-acid substitution in the coat protein of Melon necrotic spot virus causes loss of binding to the surface of Olpidium bornovanus zoospores. J. Gen. Plant Pathol. (In Press.)

21. Nagy, P. D., Pogany, J., and Simon, A. E. 1999. RNA elements required for RNA recombination function as replication enhancers in vitro and in vivo in a plus-strand RNA virus. EMBO J. 18:5653-5665.

22. Nagy, P. D., and Pogany, J. 2000. Partial purification and characterization of Cucumber necrosis virus and Tomato bushy stunt virus RNA-dependent RNA polymerases: Similarities and differences in template usage between tombusvirus and carmovirus RNA-dependent RNA polymerases. Virology 276:279-288.

23. Navarro, J. A., Genovés, A., Climent, J., Saurí, A., Martínez-Gil, L., Mingarro, I., and Pallás. V. 2006. RNA-binding properties and membrane insertion of Melon necrotic spot virus (MNSV) double gene block movement proteins. Virology 356:57-67.

24. Nieto, C., Moral, M., Orjeda, G., Clepet, C., Monfort, A., Sturbois, B., Puigdomenech, P., Pitrat, M., Caboche, M., Dogimont, C., Galcia-Mas, J., Aranda, M. A., and Bendahmane, A. 2006. An eIF4E allele confers resistance to an uncapped and non-polyadenylated RNA virus in melon. Plant J. 48:1-11.

25. Ohto, Y. 2003. Effects of air temperature conditions on symptom development and masking of wheat yellow mosaic disease (WYM). Annu. Rep. Plant Prot. North Jpn. 54:41-46.

26. Panavas, T., and Nagy, P. D. 2003. The RNA replication enhancer element of tombusviruses contains two interchangeable hairpins that are functional during plus-strand synthesis. J. Virol. 77:258-269.

27. Ray, D., Na, H., and White, K. A. 2004. Structural properties of a multifunctional T-shaped RNA domain that mediate efficient tomato Bushy stunt virus RNA replication. J. Virol. 78:10490-10500.

28. Ryabov, E. V., Fraser, G., Mayo, M. A., Barker, H., and Taliansky, M. 2001. Umbravirus gene expression helps Potato leafroll virus to invade mesophyll tissues and to be transmitted mechanically between plants. Virology 286:363-372

29. Ryang, B. S., Kobori, T., Matsumoto, T., Kosaka, Y., and Ohki, S. T. 2004. Cucumber mosaic virus $2 \mathrm{~b}$ protein compensates for restricted systemic spread of Potato virus $Y$ in doubly infected tobacco. J. Gen. Virol. 85:3405-3414.

30. Ryden, K., and Person, P. 1986. Melon necrotic spot-A new virus disease in Sweden. Vaxtskyddsnotiser 50:130-132.

31. Sakata, Y., and Sugiyama, M. 2002. Characteristics of Japanese cucurbits. Proceedings of the second international symposium on cucurbits. Acta Hort. 588:195-203.

32. Srinivasan, I., and Tolin, S. A. 1992. Detection of three viruses of clovers by direct tissue immunoblotting. Phytopathology 82:721.

33. Suzuki, E., and Masuda, S. 1961. Studies on muskmelon (Cucumis melo L. var. reticulatus NAUIN) The fluctuation of sugar amount in Earls Favorite. Bull. Educ. Fac. Shizuoka Univ. Nat. Sci. Ser. 12:205-213.

34. Szittya, G., Silhavy, D., Molnar, A., Havelda, Z., Lovas, A., Lakatos, L., Banfalvi, Z., and Burgyan, J. 2003. Low temperature inhibits RNA silencing-mediated defense by the control of siRNA generation. EMBO J. 22:633-640

35. Teakle, D. S., and Thomas, B. J. 1985. Effect of heat on zoospore motility and multiplication of Olpidium radicale and Olpidium brassicae. Ann. Appl. Biol. 107:11-15.

36. Wege, C., and Siegmund. D. 2006. Synergism of a DNA and an RNA virus: Enhanced tissue infiltration of the begomovirus Abutilon mosaic virus (AbMV) mediated by Cucumber mosaic virus (CMV). Virology 357:10-28.

37. Whitham, S., Dinesh-Kumar, S. P., Choi, D., Hehl, R., Corr, C., and Baker, B. 1994. The product of the tobacco mosaic virus resistance gene $N$ : Similarity to Toll and the Interleukin-1 receptor. Cell 78:1101-1115.

38. Yang, H., Gottlieb, P., Wei, H., Bamford, D. H., and Makeyev, E. V. 2003. Temperature requirements for initiation of RNA-dependent RNA polymerization. Virology 314:706-715.

39. Yoshida, K., Goto, T., Nemoto, M., and Tsuchizaki, T. 1980. Five viruses isolated from melon (Cucumis melo L.) in Hokkaido. Annu. Phytopathol. Soc. Jpn. 46:339-348. 